$\xi=$

\title{
Dimethylnitrosamine (DMN) exposed rats: Vernonia amygdalina pre-treatment enhances immunity, hepatic and renal function
}

\author{
Usunobun Usunomena ${ }^{1}$, Okolie P. Ngozi $^{2}$ \\ ${ }^{I}$ Department of Basic Sciences (Biochemistry Unit), Faculty of Basic and Applied Sciences, Benson, Idahosa University, \\ P.M.B. 1100, Benin City, Edo state, Nigeria \\ ${ }^{2}$ Department of Biochemistry, Faculty of Life Sciences, University of Benin, Benin City, Edo state, Nigeria \\ *Corresponding author E-mail:uusunobun@biu.edu.ng
}

\begin{abstract}
Background: The occurrence of dietary and environmental chemicals such as dimethylnitrosamine (DMN) in drinks and foods including fish and meat as well as fresh supermarket products is well established. This study evaluated protective effect of ethanolic leaf extract of Vernonia amygdalina (VAE) on liver synthetic molecules, kidney function and hematological parameters in acute dimethylnitrosamine (DMN)-induced hepatic toxicity in wistar male rats.

Methods: Experimental rats divided into four groups of six rats each were used. The first group was untreated and served as control. The second group was orally administered VAE ( $400 \mathrm{mg} / \mathrm{kg}$ ) only for seven days. The third group was pre-treated with VAE (400mg/kg) for 7 days and administered 20mg/kg DMN $24 \mathrm{hrs}$ after VAE pre-treatment. Rats of the fourth group were given 20mg/kg DMN alone same time with that of group 3. All rats were sacrificed $48 \mathrm{hrs}$ after DMN administration.

Results: In rats administered $20 \mathrm{mg} / \mathrm{kg}$ DMN, VAE pre-treatment at $400 \mathrm{mg} / \mathrm{kg}$ significantly increased total protein, albumin, White blood cell (WBC), Red blood cell (RBC), Hemoglobin (Hb), packed cell volume (PCV) and Platelets while it significantly decreased total bilirubin, urea and creatinine compared to $\mathrm{DMN}$-alone administered rats.

Conclusion: This study suggest that VAE pre-treatment exert its ameliorative effect against DMN-induced hematological and biochemical alterations possibly by preventing the decline of antioxidant defense system and could be prescribed as adjunct to dietary therapy.
\end{abstract}

Keywords:Dimethylnitrosamine; Hematology; Kidney, Liver; Vernonia amygdalina.

\section{Introduction}

Liver disease and toxicity is common especially with many drug treatments. DMN is a potent hepatotoxin, carcinogen and mutagen (George et al. 2001) which exerts carcinogenic effects and induces hepatic necrosis through metabolic activation by CYP2E1 (Guengerich et al. 1991). Activation of DMN by CYP2E1 in mouse liver has been shown to stimulate Kupffer cells leading to generation of superoxide and other reactive oxygen species (ROS) capable of damaging liver cells (Teufelhofer et al. 2005).

Vernonia amygdalina, popularly called bitter leaf and belonging to the Compositae family, is one of the plants with acclaimed folk medicinal usage and is a widely used local plant in Nigeria for both therapeutic and nutritional purposes. Vernonia amygdalina is rich in phytochemicals and antioxidants such as flavonoids, vitamin C, saponins, tannins, alkaloids and steroids as well as minerals including sodium, potassium, calcium, iron, magnesium etc (Usunobun \& Okolie 2015). Other than the common metabolites and minerals, Vernonia amygdalina also contain several active secondary metabolites including vernodalin, vernodalol, vernolide, luteolin, luteolin 7-O- $\beta$-glucoronide, leteolin 7-O- $\beta$-glucoside, vernonioside D and E and vernolepin (Igile et al. 1994, Jisaka et al. 1992,Erasto et al. 2006).Vernonia amygdalina have been proved in human medicine to possess potent anti-malarial and anti-helminthic properties (Abosi \& Raseroka 2003) as well as anti-tumorigenic properties (Izevbigie et al. 2004). This study is aimed at determining the effect of ethanolic leaf extract of
Vernonia amygdalina on liver synthetic molecules, kidney function and hematological parameters in DMN exposed wistar rats.

\section{Materials and methods}

2.1. Collection, identification, preparation and extraction of plant leaves

Fresh leaves of Vernonia amygdalina were purchased from a local market in Benin City, Edo state, Nigeria. The leaves were identified by a Botanist in the Department of Basic Sciences, Faculty of Basic and Applied Sciences, Benson Idahosa University, Benin city, Edo State. The Vernonia amygdalina leaves were separated from the stalk, washed and air-dried at room temperature $\left(24^{\circ} \mathrm{C}\right)$ and then pulverized, crushed into fine powder and weighed.

Ethanolic extracts of the plant leaves was prepared by soaking $400 \mathrm{~g}$ of the dry powdered plant leaves in one (1) litre of absolute ethanol at room temperature for $48 \mathrm{hrs}$. The extract was then filtered first through a Whatmann filter paper No. $42(125 \mathrm{~mm})$ and then through cotton wool. The extract was thereafter concentrated using a rotary evaporator with the water bath set at $40^{\circ} \mathrm{C}$ to onetenth its original volume and then finally freeze dried. The dried residue (crude extract) was then stored at $4^{\circ} \mathrm{C}$ and used on each day of our experiments. 


\subsection{Experimental animals, DMN and extract admin- istration}

Male wistar albino rats divided into four groups of six (6) rats each, weighing between 160-195g were obtained from the Animal Unit facility of the University of Ibadan, Oyo state, Nigeria and housed in wooden cages in the animal house of the Department of Biochemistry, University of Benin. The rats were maintained under controlled environmental conditions (temperature- $24{ }^{\circ} \mathrm{C}$; relative humidity-50-70\%; $12 \mathrm{~h} \mathrm{light/dark} \mathrm{cycle),} \mathrm{housed} \mathrm{for} \mathrm{one}$ week after their arrival to the animal house for acclimatization. The rats had free access to drinking water and normal pellet diet (NPD) ad libitum until they were assigned to individual groups. Institutional Animal Ethical Committee permission was obtained before performing the experiments.

DMN used in this work was synthesized in a fume chamber at the Department of Biochemistry, University of Ibadan, Oyo state, Nigeria, according to the method of Vogel (1971).

A total of 24 rats divided into 4 groups were used. Group 1 served as control and was given normal saline, Group 2 received $400 \mathrm{mg} / \mathrm{kg}$ Vernonia amygdalina only for seven (7) days consecutively, Group 3 received 400mg/kg Vernonia amygdalina for 7 days consecutively followed by oral administration of a single dose of $20 \mathrm{mg} / \mathrm{kg} \mathrm{DMN}$ (dissolved in $0.15 \mathrm{MNaCl}$ ), on day 8 (48 hours before sacrifice) while Group 4 received oral administration of single dose of $20 \mathrm{mg} / \mathrm{kg}$ DMN (dissolved in $0.15 \mathrm{MNaCl}$ ) on day 8. Before use, the Vernonia amygdalina leaf extract was reconstituted in distilled water and administered orally. All rats were sacrificed on the tenth day of the study by cardiac puncture and blood collected via the ocular vein in either EDTA bottles for hematology or in plain tubes. Blood collected in plain bottles were allowed to stand for $45 \mathrm{~min}$ before it was centrifuged at 4,000 rpm for 30 min. Serum was stored at $-20^{\circ} \mathrm{C}$ until analyzed.

\subsection{Biochemical assays}

Serum total bilirubin, total protein, albumin and urea were determined using the RANDOX Kit according to themanufacturer's instructions while serum creatinine was determined using the Jaffe' method. Hematology was carried using full automated blood cell counter PCE -210N (ERMA INC., USA).

\subsection{Statistical analysis}

Data obtained from the study were expressed as mean value \pm standard deviation. Differences between means of control and tested groups were determined using Statistical Package for social scientist (SPSS). A probability level of less than $5 \%(\mathrm{P}<0.05)$ was considered significant.

\section{Results}

The detailed results of the body and tissue weights are presented in Table 1. There was a reduction in body weight gain of DMN administered rats when compared to extract and control rats. However, DMN administered rats pretreated with ethanolic leaf extract of $400 \mathrm{mg} / \mathrm{kg}$ Vernonia amygdalina caused an increase in the body weight gain compared to DMN alone administered rats. The effect of ethanolic leaf extracts of Vernonia amygdalina on acute DMN-induced liver and kidney injury were evaluated by determining the levels of total protein, albumin, total bilirubin, urea and creatinine as shown in Table 2. Vernonia amygdalina lowered the levels of urea, creatinine and total bilirubin and significantly increased $(\mathrm{p}<0.05)$ total protein and albumin when compared to acute DMN alone group.
Table 1: Effect of Vernonia amygdalina on Body and Organ Weight in Acute DMN-Induced Toxicity in Rats.

\begin{tabular}{|c|c|c|c|c|c|}
\hline Treatment & $\begin{array}{l}\text { Initial } \\
\text { body } \\
\text { weight } \\
\text { (g) }\end{array}$ & $\begin{array}{l}\text { Final } \\
\text { body } \\
\text { weight } \\
\text { (g) }\end{array}$ & $\begin{array}{l}\text { Weight } \\
\text { gain } \\
\text { (g) }\end{array}$ & $\begin{array}{l}\text { Relative } \\
\text { liver } \\
\text { weight } \\
(\%)\end{array}$ & $\begin{array}{l}\text { Relative } \\
\text { kidney } \\
\text { Weight } \\
(\%)\end{array}$ \\
\hline $\begin{array}{l}\text { Control } \\
\text { (normal } \\
\text { saline) }\end{array}$ & $\begin{array}{l}166.20 \pm 1 \\
47\end{array}$ & $\begin{array}{l}188.00 \pm 4 \\
55\end{array}$ & $\begin{array}{l}21.80 \pm 3 \\
08\end{array}$ & $\begin{array}{l}3.09 \pm 0.0 \\
7^{\mathrm{a}}\end{array}$ & $\begin{array}{l}0.70 \pm 0 \\
02^{\mathrm{a}}\end{array}$ \\
\hline $\begin{array}{l}\text { VAE } \\
\text { alone } \\
(400 \mathrm{mg} / \mathrm{k} \\
\text { g) }\end{array}$ & $\begin{array}{l}165.17 \pm 2 \\
34\end{array}$ & $\begin{array}{l}194.00 \pm 6 \\
44\end{array}$ & $\begin{array}{l}28.83 \pm 4 \\
10\end{array}$ & $\begin{array}{l}3.04 \pm 0.1 \\
1^{\mathrm{a}}\end{array}$ & $\begin{array}{l}0.69 \pm 0 . \\
02^{\mathrm{a}}\end{array}$ \\
\hline $\begin{array}{l}\text { VAE } \\
(400 \mathrm{mg} / \mathrm{k} \\
\mathrm{g})+\mathrm{DMN} \\
(20 \mathrm{mg} / \mathrm{kg})\end{array}$ & $\begin{array}{l}175.20 \pm 3 \\
41\end{array}$ & $\begin{array}{l}193.50 \pm 6 \\
01\end{array}$ & $\begin{array}{l}19.10 \pm 3 \\
00\end{array}$ & $\begin{array}{l}3.39 \pm 0.0 \\
8^{\mathrm{b}}\end{array}$ & $\begin{array}{l}0.71 \pm 0 . \\
02^{\mathrm{a}}\end{array}$ \\
\hline $\begin{array}{l}\text { DMN } \\
\text { alone } \\
(20 \mathrm{mg} / \mathrm{k})\end{array}$ & $\begin{array}{l}192.29 \pm 2 . \\
76\end{array}$ & $\begin{array}{l}199.17 \pm 6 \\
86\end{array}$ & $\begin{array}{l}6.88 \pm 4.1 \\
0\end{array}$ & $\begin{array}{l}3.41 \pm 0.1 \\
0^{\mathrm{b}}\end{array}$ & $\begin{array}{l}0.73 \pm 0 . \\
11^{\mathrm{a}}\end{array}$ \\
\hline
\end{tabular}

Values are expressed as Mean $\pm \mathrm{SD},(\mathrm{n}=6)$, VAE $=$ Vernonia amygdalina, $\mathrm{DMN}=$ Dimethylnitrosamine

Mean values in each column having different superscript $(a, b, c)$ are significantly different $(\mathrm{p}<0.05)$.

Table 2: Effect of Vernonia amygdalina on Serum Liver Synthetic Ability and Kidney Function in Acute DMN-Induced Toxicity in Rats

\begin{tabular}{llllll}
$\begin{array}{l}\text { Treatment } \\
\text { groups }\end{array}$ & $\begin{array}{l}\text { TP } \\
(\mathrm{g} / \mathrm{dl})\end{array}$ & $\begin{array}{l}\text { Albumin } \\
(\mathrm{g} / \mathrm{dl})\end{array}$ & $\begin{array}{l}\mathrm{TB} \\
(\mathrm{mg} / \mathrm{dl})\end{array}$ & $\begin{array}{l}\text { Creati- } \\
\text { nine } \\
(\mathrm{mg} / \mathrm{dl})\end{array}$ & $\begin{array}{l}\text { Urea } \\
(\mathrm{mg} / \mathrm{dl})\end{array}$ \\
\hline $\begin{array}{l}\text { Control } \\
\text { (normal }\end{array}$ & $\begin{array}{l}7.50 \pm 0.2 \\
8^{\mathrm{a}}\end{array}$ & $\begin{array}{l}4.53 \pm 0.0 \\
5^{\mathrm{a}}\end{array}$ & $\begin{array}{l}0.69 \pm 0.1 \\
1^{\mathrm{a}}\end{array}$ & $\begin{array}{l}0.70 \pm 0.0 \\
8^{\mathrm{a}}\end{array}$ & $\begin{array}{l}30.00 \pm 6.5 \\
6^{\mathrm{a}}\end{array}$ \\
$\begin{array}{l}\text { VAE } \\
\text { alone }(400\end{array}$ & $7.83 \pm 0.5$ & $4.27 \pm 0.2$ & $0.71 \pm 0.1$ & $0.60 \pm 0.0$ & $32.33 \pm 7.2$ \\
$\mathrm{mg} / \mathrm{kg})$ & $3^{\mathrm{a}}$ & $6^{\mathrm{a}}$ & $7^{\mathrm{a}}$ & $3^{\mathrm{a}}$ & $3^{\mathrm{a}}$ \\
$\begin{array}{l}\mathrm{VAE} \\
(400 \mathrm{mg} / \mathrm{kg}\end{array}$ & $5.27 \pm 0.9$ & $2.40 \pm 0.2$ & $1.51 \pm 0.0$ & $1.10 \pm 0.0$ & $72.26 \pm 6.4$ \\
$+\mathrm{DMN}$ & $1^{\mathrm{b}}$ & $2^{\text {dd }}$ & $9^{\mathrm{b}}$ & $8^{\mathrm{b}}$ & $3^{\mathrm{b}}$ \\
$(20 \mathrm{mg} / \mathrm{kg})$ & & & & & \\
$\begin{array}{l}\mathrm{DMN} \\
\text { alone }\end{array}$ & $3.97 \pm 0.6$ & $1.73 \pm 0.8$ & $2.94 \pm 0.0$ & $1.27 \pm 0.0$ & $92.00 \pm 4.5$ \\
$(20 \mathrm{mg} / \mathrm{kg})$ & $0^{\mathrm{c}}$ & $7^{\mathrm{c}}$ & $3^{\mathrm{c}}$ & $5^{\mathrm{c}}$ & $6^{\mathrm{c}}$ \\
\hline
\end{tabular}

Values are means $\pm \mathrm{SD} ; \mathrm{n}=5, \mathrm{VAE}=$ Vernonia amygdalina ethanolic extract, $\mathrm{DMN}=$ Dimethylnitrosamine, $\mathrm{TP}=$ Total Protein, $\mathrm{TB}=$ Total bilirubin

Mean values in each column having different superscript $(a, b, c)$ are significantly different $(\mathrm{p}<0.05)$.

Results in Table 3 given below shows that rats administered DMN significantly had decreased WBC, RBC, Hb, PCV and Plt Count whereas Vernonia amygdalina leaf extract pre-treatment significantly attenuated the hematological parameters in DMN administered rats towards the control values.

Table 3: Effect of Vernonia amygdalina on Haematological Parameters in Acute DMN-Induced Toxicity in Rats.

$\begin{array}{llllll}\begin{array}{l}\text { Treatment } \\ \text { groups }\end{array} & \begin{array}{l}\text { WBC } \\ (\mathrm{x} \\ \left.10^{3} / \mathrm{ul}\right)\end{array} & \begin{array}{l}\text { RBC } \\ \left(\mathrm{x} 10^{6}\right.\end{array} & \begin{array}{l}\mathrm{Hb} \\ (\mathrm{g} / \mathrm{dl})\end{array} & \text { PCV }(\%) & \begin{array}{l}\text { Plt } \\ \text { Count } \\ (\mathrm{x}\end{array} \\ \left.10^{3} / \mathrm{ul}\right)\end{array}$

Values are means $\pm \mathrm{SD} ; \mathrm{n}=3, \mathrm{VAE}=$ Vernonia amygdalina ethanolic extract, $\mathrm{DMN}=$ Dimethylnitrosamine, $\mathrm{WBC}=$ White blood cells, $\mathrm{RBC}=$ Red blood cells, $\mathrm{Hb}=$ Hemoglobin, $\mathrm{PCV}=$ Packed cell volume, Plt count $=$ Platelet count

Mean values in each column having different superscript (a, b, c, d) are significantly different $(\mathrm{P}<0.05)$. 


\section{Discussion}

The liver not only synthesizes the proteins for its needs but produces numerous export proteins among which is serum albumin which plays important biological roles including maintenance of plasma oncotic pressure (Peter 1996). In this study, DMN induced liver damage in rats as indicated by the decrease in levels of serum albumin and total protein similar to our previous study (Usunobun 2014). However, Vernonia amygdalina pre-treatment significantly protected the rats against DMN-induced hepatotoxicity as evidenced by the significant increase in serum total protein and albumin compared to DMN-alone treated rats. In an earlier study by Muthulingam (2002), oral administration of chloroform and ethyl acetate fractions of Astercanthalongifolia and also silymarin to $\mathrm{CCl}_{4}$ treated rats showed significantly increased serum protein level. Also in a report by Ekam et al (2012), there was a significant increase $(\mathrm{P}<0.05)$ in total protein in all group treated with the various fractions of Vernonia amygdalina compared to the paracetamol alone group.

Bilirubin is a well-known metabolic breakdown product of blood heme with great biological and diagnostic values (Chowdhury et al. 1989). The increase in total bilirubin in this study corroborate our previous study where we reported increased liver function enzymes in rats administered single dose of $20 \mathrm{mg} / \mathrm{kg}$ or $12 \mathrm{mg} / \mathrm{kg}$ DMN (Usunobun et al. 2015, Usunobun, 2014). Thus the increase in total bilirubin level in the serum of DMN-alone induced rats indicates damage to hepatic cells. On the other hand, DMNadministered rats orally pre-treated with ethanolic leaf extract of $400 \mathrm{mg} / \mathrm{kg}$ Vernonia amygdalina caused significant decrease in level of total bilirubin compared to DMN-alone treated rats. The leaf extract decreased $(\mathrm{P}<0.05) \mathrm{DMN}$-induced elevated total bilirubin levels, indicating protection of liver structural integrity. It is possible that Vernonia amygdalina induced UDPglucuronosyltransferase that catalyzed the conjugation of bilirubin thereby increasing its hydrophilicity and subsequently excretion. The protective effect of Vernonia amygdalina may be due to presence of active compounds such as flavonoids as well as minerals and other antioxidants (Usunobun \& Okolie 2015).

In this study, there was also a marked decrease in body weight gain in rats administered DMN alone compared to controls. However, Vernonia amygdalina pre-treatment prior to DMN administration caused an increase in body weight gain compared to DMN-alone administered rats. There was also a significant increase in relative liver weight in rats administered DMN alone compared to control rats. The results was similar to that of Ismail et al (2009) who reported that relative liver weight for $\mathrm{CCl}_{4}$ group showed significant increase as compared to the control groups. Also, the present results were similar with those of Hashimoto et al (1999), who showed that treatment with $\mathrm{CCl}_{4}$ and phenobarbital causes liver deformity and high percentage of liver weight in the group injected with $\mathrm{CCl}_{4}$ and fed on basal diet. However, Vernonia amygdalina pre-treatment prior to DMN administration led to a decrease of relative liver weight compared to rats administered DMN alone.

WBCs carry out the many tasks required to protect the body against disease-causing microbes and abnormal cells. Platelets play a very important role in the coagulation of blood to help stop bleeding. Hemoglobin, a substance formed with iron, carries oxygen through the blood. In this study, DMN administration decreased WBCs, Platelets, RBCs, PCV, and Hb in DMN treated group compared to control groups similar to our previous study (Usunobun, 2014). However, Vernonia amygdalina pre-treatment prior to DMN administration enhanced the hematological indices, thus indicating that Vernonia amygdalina improve immunity function and decrease inflammation.

Renal function indices such as serum urea, creatinine and uric acid can be used to evaluate the functional capacity of the nephrons of animals (Yakubu et al. 2003). The increase in serum creatinine and urea contents of rats in DMN administered group observed in this study may be attributed to a compromised renal functional capacity. DMN intoxication might have interfered with creatinine and urea metabolism leading to increased synthesis or it might have compromised all or part of kidney functional capacity in tubular and glomerular excretion (Zilva et al. 1991). However, pretreatment with extracts of Vernonia amygdalina prior to DMN administration significantly decreased serum urea and creatinine levels, thereby enhancing kidney protection.

In conclusion the protective effect observed by Vernonia amygdalina against acute DMN toxicity may be due to bioactive compounds such as flavonoids, saponins and tannins as well as the plant ability to maintain endogenous antioxidants.

\section{References}

[1] Abosi AO \& Raseroka BH. (2003). In vivo antimalarial activity of Vernonia amygdalina. British Journal of Biomedical Science 60(2), 89-91.

[2] Chowdhury JR, Wolkoff AW, Arias IM, (1989) in: Scriver CR, Beaudet AL, Sly WS, Valle D, (Eds.), The Metabolic Basis ofInherited Diseases, McGraw Hill, New York, pp. 1367-1408.

[3] Ekam VS, Johnson JT, Dasofunjo K, Odey MO. \& Anyahara SE. (2012). Total protein, albumin and globulin levels following the administration of activity directed fractions of Vernonia amygdalina during acetaminophen induced hepatotoxicity in wistar rats. Annals of Biological Research 3(12), 5590-5594

[4] Erasto P, Griersoon DS, \&Afolayan AJ (2006). Bioactive sesquiterpene lactones from the leaves of Vernonia amygdalina. Journal of Ethnopharmacology 106 , 120.http://dx.doi.org/10.1016/j.jep.2005.12.016.

[5] George J, Rao KR, Stern R, \& Chandrakasan G. (2001). Dimethylnitrosamine-induced liver injury in rats: the early deposition of collagen. Toxicology156(2-3) 138.http://dx.doi.org/10.1016/S0300-483X(00)00352-8.

[6] Guengerich FP, Kim DH \& Iwasaki M. (1991). Role of human cytochrome P-450 IIE1 in the oxidation of many low molecular weight cancer suspects. Chemical Research and Toxicology 4(2), 168-179.http://dx.doi.org/10.1021/tx00020a008.

[7] Hashimoto M,Kothary PC. \&Raper SE. (1999). Phenobarbital in comparison with carbon tetrachloride and phenobarbital-induced cirrhosis in rat liver regeneration. Journal of Surgical Research 81(2), 164-169. http://dx.doi.org/10.1006/jsre.1998.5424.

[8] Igile GO, Oleszek W, Jurzysta M, Burda S, Fafunso M, \& Fasanmade AA (1994). Flavonoids from Vernonia amygdalina and their antioxidant activities. Journal of Agriculture and Food Chemistry 42, 2445-2448.http://dx.doi.org/10.1021/jf00047a015.

[9] Ismail RSA, El-Megeid AAA \& Abdel-Moemin AR. (2009). Carbon tetrachloride-induced liver disease in rats: the potential effect of supplement oils with vitamins $\mathrm{E}$ and $\mathrm{C}$ on the nutritional status,"German Medical Science 7, 1-10.

[10] Izevbige EB, Bryant TL \& Walker A. (2004). A novel natural hibitor of extracellular signal regulated kinases and human breast cancer cell growth. Experimental Biology and Medicine 229(2), 163 169.

[11] Jisaka M, Ohigashi H, Takagaki T, Nozaki H, Tada T, Hirota M, Irie R, Huffman MA, Nishida T, Kaji M, \& Koshimizu K (1992). Bitter steroid glucosides, Vernoniosides A1, A2 and A3 and realted B1 from a possible medicinal plant, Vernonia amygdalina, used by wild chimpanzees. Tetrahedron 48, 625632.http://dx.doi.org/10.1016/S0040-4020(01)88123-0.

[12] Muthulingam M. (2002). Studies on the curative efficacy of Astercanthalongifolia on carbon tetrachloride induced hepatotoxicity in rats. Ph.D.Thesis, Annamalai University.

[13] Peter T. Jr. (1996). All about Albumin, Biochemistry, Genetics, and Medical Applications, Academic Press, San Diego.

[14] Teufelhofer O, Parzefall W, Kainzbauer E, Ferk F, Freiler C, Knasmuller S, Elbling L, Thurman R \& Schulte-Hermann R. (2005). Superoxide generation from Kupffer cells contributes to hepatocarcinogenesis: Studies on NADPH oxidase knockout mice. Carcinogenesis 329.http://dx.doi.org/10.1093/carcin/bgh320.

[15] Usunobun U. (2014). Antihepatotoxic efficacy of Vernonia amyg dalinaethanolic leaf extract on Dimethylnitrosamine (DMN)induced liver damage in rats. International Journal of Healthcare and Biomedical Research 03(01), 89-98

[16] Usunobun U. \& Okolie NP (2015). Phytochemical, trace and mineral composition of Vernonia amygdalina leaves. International Journal of Biological and Pharmaceutical Research 6(5), 393-399.

[17] Usunobun U, Okolie P.N, \&Eze GI (2015). Effect of Vernonia amygdalina on some biochemical indices in Dimethylnitrosamine 
(DMN) induced liver injury in rats. International Journal of Animal Biology 1(4), 99-105.

[18] Vogel AI. (1971). A textbook of practical organic Chemistry including qualitative organic analysis. Longman group limited, London. Pp 426.

[19] Yakubu MT, Bilbis LS, Lawal M, \& Akanji M.A (2003). Evaluation of selected parameters of rat liver and kidney function following repeated administration of yohimbine. Biokemistri 15, 50-56.

[20] Zilva JF, Panmall PR, \& Mayne PD (1991). Clinical Chemistry in Diagnosis and Treatment. 5th Edition. England Clays Ltd, St. Ives Plc, England. 